\title{
UTANG PIUTANG DALAM PERSPEKTIF EKONOMI ISLAM
}

\author{
Tri Nadhirotur Ro'fiaha, \\ Nurul Fadilab \\ a,b,c Fakultas Ekonomi dan Bisnis Islam, Universitas Islam Zainul \\ Hasan Genggong Probolinggo \\ Email: trinadirohrofiah09@gmail.com
}

\begin{abstract}
The practice of accounts payable transactions as one aspect of fulfilling one's life through social interactions. A transaction that is full of privileges and virtues that Allah has promised for the doer (the creditor).

The practice of accounts payable that we know, in addition to having a positive side through the principle of please help, but often it is also a starting point for disputes and enmity between humans. This will become evident when in practice, humans ignore some of the fundamental principles that form the framework for legalizing the practice of helping to help; namely honesty.
\end{abstract}

Keywords : Receivables Debt and Islamic Economy

\section{PENDAHULUAN}

Adanya kecenderungan dalam melakukan interaksi sosial adalah salah bukti bahwa manusia adalah makhluk lemah yang tidak akan sempurna dalam mempertahankan kehidupan tanpa bantuan dan peranan orang lain dalam 
hidupnya. Tentunya hal semacam ini berlaku dalam segala hal, termasuk dalam pemenuhan rezeki. Banyak cara yang dilakukan Allah Swt. dalam menyampaikan rezeki pada hamba-Nya. Diantaranya adalah melalui disyariatkannya praktik transaksi hutang piutang sebagai salah satu aspek pemenuh hajat hidup via interaksi sosial. Sebuah transaksi yang sarat akan keistimewaan dan keutamaan yang dijanjikan Allah bagi pelakunya (pemberi hutang).

Praktik hutang piutang yang kita tahu, selain terdapat sisi positif melalui asas tolong menolongnya, namun tak jarang juga menjadi titik mula perselisihan dan permusuhan diantara manusia. Hal itu akan menjadi nyata mana kala dalam praktiknya, manusia mengacuhkan beberapa prinsip fundamen yang menjadi rangka bangun dilegalkannya praktik tolong menolong ini; yakni kejujuran. Seolah sudah menjadi tabiat manusia jika bersinggungan dengan hal-hal yang bernuansa harta keduniawian mereka lupa dan mudah terlena begitu saja hingga memunculkan sesal di kemudian hari.

Berkat ke Maha Tahu-an Allah akan hal ini, selain di legalkannya praktik hutang piutang, Allah Swt. sekaligus membuat semacam seperangkat formulasi khusus yang harus diperhatikan dan dijalankan oleh manusia guna menghindarkan mereka dari perselisihan dan persengketaan yang timbul dikemudian hari. Lebih jauh, dengan formulasi ini Allah Swt. ingin menghindarkan mereka dari mandeg-nya aktivitas tolong-menolong diantara manusia akibat ketiadaan sifat amanah dan saling percaya lagi antara satu dan yang lainnya.

Dengan latar belakang diatas, setidaknya dalam goresan jurnal singkat ini penulis ingin mengurai secara sederhana beberapa hal, berpegang dengan beberapa kitab tafsir terkait pengertian hutang piutang sesuai dalam surat al-Baqarah 282- 


\section{HASIL DAN PEMBAHASAN}

\section{Pengertian Utang Piutang}

Secara etimologi, qardh berarti آلْقَطْعُ (potongan). Harta yang dibayarkan kepada muqtarid (yang diajak akad qarad) dinamakan qarad, sebab merupakan potongan dari harta muqrid (orang yang membayar). ${ }^{1}$

Dalam pengertian istilah, qardh didefinisikan oleh Ulama Hanafiah sebagai berikut:

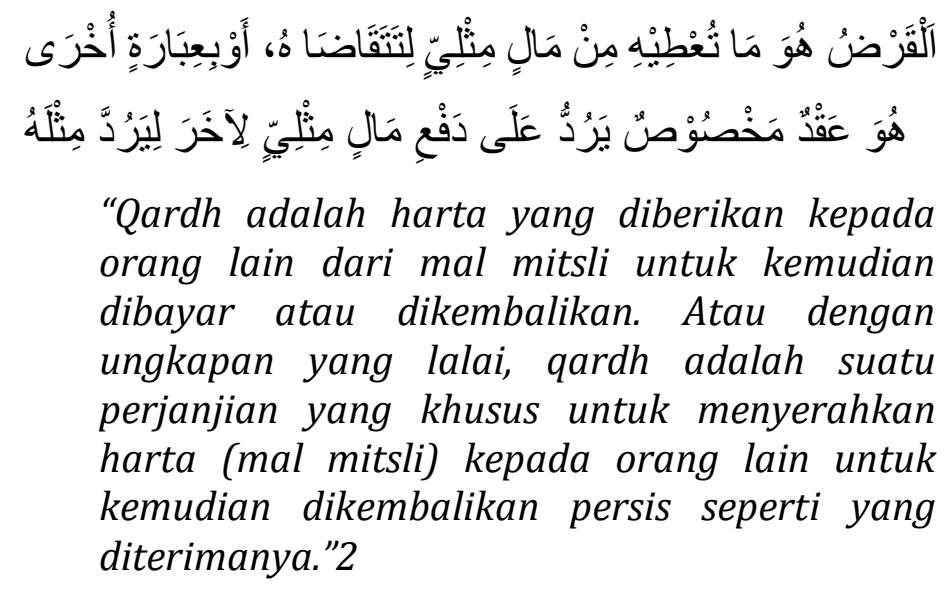

Sayid Sabiq memberikan definisi qardh sebagai berikut

:

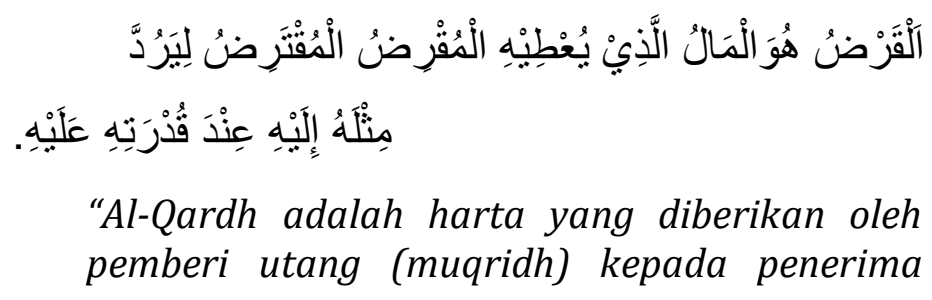

${ }^{1}$ Rachmat Syafei, Fiqh Muamalah (Bandung: CV. Pustaka Setia), 151.

${ }^{2}$ Wahbah Zuhaily, Fiqih Islam Wa Adilatuhu, (Damaskus: Darul fikr, 1985), 720 . 
utang (muqtaridh) untuk kemudian dikembalikan kepadanya (muqridh) seperti yang diterimanya, ketika ia telah mampu membayarnya."3

Hanabilah sebagai dikutip oleh Ali Fikri memberikan definisi qardh sebagai berikut:

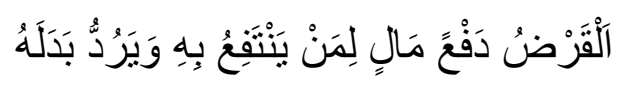

"Qardh adalah memberikan harta kepada orang yang memanfaatkannya dan kemudian mengembalikan penggantinya".4

Dari definisi-definisi diatas, dapat diambil intisari bahwa qardh adalah suatu akad antara dua pihak, di mana pihak pertama memberikan uang atau barang kepada pihak kedua untuk dimanfaatkan dengan ketentuan bahwa uang atau barang tersebut harus dikembalikan persis seperti yang ia terima dari pihak pertama. Baik Hanafiah dalam definisi yang pertama, maupun Hanabilah, keduanya memandang bahwa qardh diartikan sebagai harta yang diberikan oleh muqridh kepada muqtaridh, yang pada suatu saat harus dikembalikan.

Di samping itu, dari definisi yang telah disebutkan di atas dapat dipahami bahwa qardh juga bisa diartikan sebagai akad atau transaksi antara dua pihak. Jadi, dalam hal ini qard diartikan sebagai perbuatan memberikan sesuatu kepada pihak lain yang nantinya harus dikembalikan, bukan sesuatu (mal atau harta) yang diberikan itu.

Al-Qardhu (memberikan utang) merupakan kebajikan yang membawa kemudahan kepada muslim yang mengalami kesulitan dan membantunya dalam memenuhi kebutuhan.

\footnotetext{
${ }^{3}$ Sayyid Sabiq, Fiqh As-Sunnah, (Beirut: Dar Al-Fikr1981), 182.

${ }^{4}$ Ali Fikri, Al-Muamalat Al-Maddiyah wa Al-Adabiyah, (Mesir: Mushtafa AlBabiy Al-Halabiy, 1356 H), 346.
} 
Sedangkan, mengutang tidaklah terhitung sebagai bentuk meminta-minta yang makruh, karena Rasulullah sendiri pernah berutang kepada orang lain.5

\section{Ayat tentang utang piutang}

Beberapa ayat al-Quran yang membahas tentang hutang piutang:

\section{Al-Baqarah ayat 282}

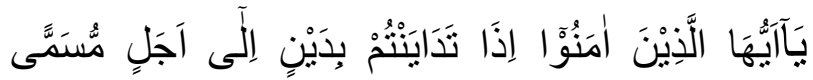

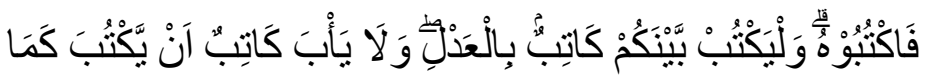

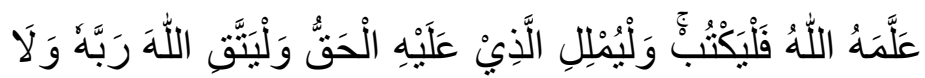

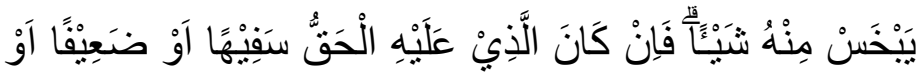

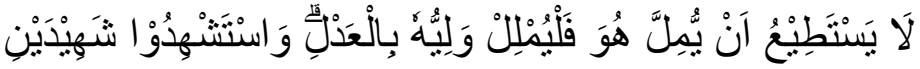

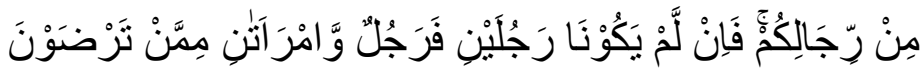

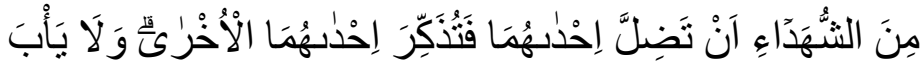

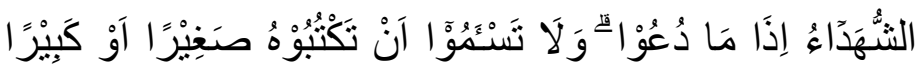

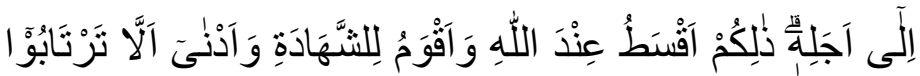

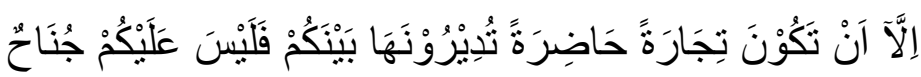

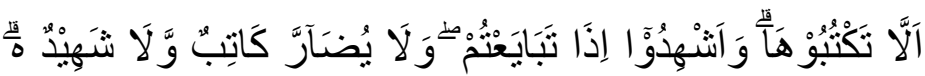

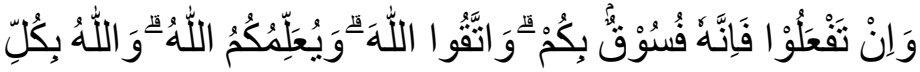
شَتْيٍٍْ عَلْيْمُ

Artinya "Hai orang-orang yang beriman, apabila kamu bermu'amalah tidak secara tunai untuk waktu yang ditentukan, hendaklah kamu

${ }^{5}$ Saleh al-Fauzan, Al-Mulakhkhasul Fiqhi,(Jakarta: Gema Insani Pres, 2005), 411. 
menuliskannya. dan hendaklah seorang penulis di antara kamu menuliskannya dengan benar. dan janganlah penulis enggan menuliskannya sebagaimana Allah mengajarkannya, meka hendaklah ia menulis, dan hendaklah orang yang berhutang itu mengimlakkan (apa yang akan ditulis itu), dan hendaklah ia bertakwa kepada Allah Tuhannya, dan janganlah ia mengurangi sedikitpun daripada hutangnya. jika yang berhutang itu orang yang lemah akalnya atau lemah (keadaannya) atau Dia sendiri tidak mampu mengimlakkan, Maka hendaklah walinya mengimlakkan dengan jujur. dan persaksikanlah dengan dua orang saksi dari orangorang lelaki (di antaramu). jika tak ada dua oang lelaki, Maka (boleh) seorang lelaki dan dua orang perempuan dari saksi-saksi yang kamu ridhai, supaya jika seorang lupa Maka yang seorang mengingatkannya. janganlah saksi-saksi itu enggan (memberi keterangan) apabila mereka dipanggil; dan janganlah kamu jemu menulis hutang itu, baik kecil maupun besar sampai batas waktu membayarnya. yang demikian itu, lebih adil di sisi Allah dan lebih menguatkan persaksian dan lebih dekat kepada tidak (menimbulkan) keraguanmu. (Tulislah mu'amalahmu itu), kecuali jika mu'amalah itu perdagangan tunai yang kamu jalankan di antara kamu, Maka tidak ada dosa bagi kamu, (jika) kamu tidak menulisnya. dan persaksikanlah apabila kamu berjual beli; dan janganlah penulis dan saksi saling sulit menyulitkan. jika kamu lakukan (yang demikian), Maka Sesungguhnya hal itu adalah suatu kefasikan pada dirimu. dan bertakwalah kepada Allah; Allah mengajarmu; dan Allah Maha mengetahui segala sesuatu. 
Al-Baqarah ayat 283

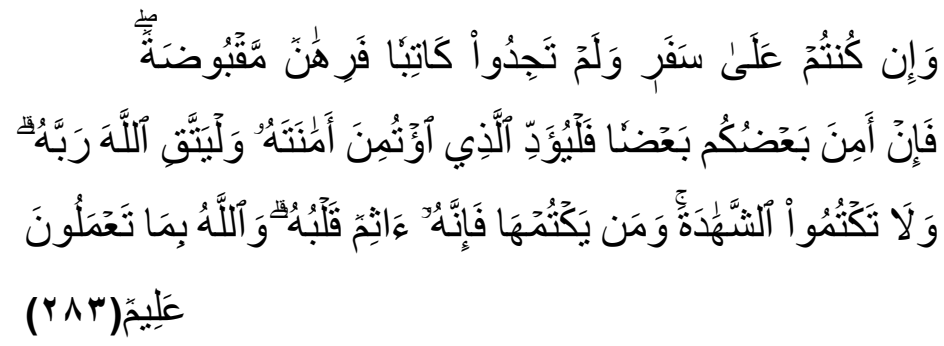

Artinya; Jika kamu dalam perjalanan (dan bermu'amalah tidak secara tunai) sedang kamu tidak memperoleh seorang penulis, maka hendaklah ada barang tanggungan yang dipegang (oleh yang berpiutang). Akan tetapi jika sebagian kamu mempercayai sebagian yang lain, maka hendaklah yang dipercayai itu menunaikan amanatnya (hutangnya) dan hendaklah ia bertakwa kepada Allah Tuhannya; dan janganlah kamu (para saksi) menyembunyikan persaksian. Dan barangsiapa yang menyembunyikannya, maka sesungguhnya ia adalah orang yang berdosa hatinya; dan Allah Maha Mengetahui apa yang kamu kerjakan.

\section{Tafsir universal tentang utang piutang Al-Baqarah ayat 282}

Wahai orang yang beriman kepada Allah dan mengikuti Rasul-Nya; Muhammad Saw.! apabila kakalian bermuamalah (berjual beli, hutang piutang, atau sewa menyewa, dan sebagainya) tidak secara tunai dalam waktu tertentu, hendaklah kamu menuliskannya untuk memelihara harta dan menghindari perselisihan. Hendaklah seorang yang dapat dipercaya menuliskannya. Janganlah orang yang diajari Allah dalam persoalan ini enggan untuk menuliskannya. Hendaklah orang yang berhutang itu 
mendiktekan hutangnya. Hendaklah ia takut kepada Tuhannya dan jangan mengurangi sedikit pun dari hutangnya. Apabila orang yang berhutang itu masih dibawah perwalian karena suka melakukan pemborosan dan penghamburan, masih kecil gila, dia tidak mampu berbicara karena bisu atau tidak mampu berbicara dengan baik dan sempurna, kewajiban mendiktekan hutang berpindah kepada orang yang ditugasi menjadi wakilnya. Mintalah saksi dua orang laki-laki muslim yang balig dan berakal dari kalangan orang-orang adil (bersih dan terpercaya). Jika tidak ada dua orang laki-laki, (boleh) seorang laki-laki dan dua orang perempuan dari saksi-saksi yang kamu ridhai supaya jika seorang lupa, seorang lagi mengingatkannya. Hendaklah saksi-saksi itu datang apabila mereka dipanggil untuk bersaksi. Dan mereka harus memberikan persaksian ketika diminta. Janganlah kamu jemu untuk menulis hutang, baik kecil maupun besar, sampai batas waktu pembayarannya. Yang demikian itu lebih adil dalam pandangan syariat, dan petunjuk Allah lebih membantu dalam persaksian, dan lebih kuat menepis keraguan dalam jenis, kadar, dan tempo pelunasan. Namun dalam transaksi tunai tidak diwajibkan penulisan. Sekalipun demikian, dianjurkan ada saksi untuk menghindari perselisihan dan perpecahan. Diwajibkan atas saksi dan penulis untuk melaksanakan persaksian dan penulisan dengan cara yang benar dan sesuai perintah Allah. jangan sampai para saksi dan para penulis mencelakakan orang yang berhutang dan yang member hutang. Jika kamu melakukan apa yang dilarang. Sesungguhnya itu adalah tindakan yang menyimpang dari perintah Allah dan kamu pantas mendapatkan akibatnya. Takutlah kepada Allah dengan melaksanakan semua yang diperintahkan kepadamu dan menjauhi segala larangannya. Allah mengajarimu semua yang baik bagi dunia dan akhiratmu. Allah Maha Mengetahui segala sesuatu. Tidak ada satu pun dari urusanmu yang 
tersembunyi bagi Allah. Dia akan membalas semua perbuatanmu. ${ }^{6}$

\section{Al-Baqarah ayat 283}

Wahai pelaku transaksi piutang, jika kalian dalam perjalanan atau halangan sejenisnya, dan kalian tidak menemukan pencatat akad piutang, maka hendaknya orang yang berhutang memberikan barang jaminan kepada pemberi hutang. Serah terima jaminan merupakan syarat sahnya gadai menurut jumhur ulama, selain madzhab Maliki yang mencukupkan ijab Kabul sebagai syaratsah gadai. Jika kalian telah saling percaya dan pemberi hutang tidak mengambil jaminan hutang, penerima hutang yang telah dipercayai tersebut mesti melunasi utangnya, tidak mengkhianati amanat, dan tidak berpaling dari kebenaran sedikit pun. Wahai para saksi, janganlah menyembunyikan kesaksian jika kalian diminta untuk bersaksi. Sebab, siapa saja yang menyembunyikan persaksian berarti hatinya kotor dan pelaku maksiat. Karena itu, Allah akan menghukumnya sebab telah mengabaikan hak pemberi hutang. Allah maha mengetahui apa pun yang kalian kerjakan. ${ }^{7}$

\section{Asbabun Nuzul ayat tentang utang piutang}

\section{Al-Baqarah ayat 282}

Dari Ibnu Abbas mengatakan bahwa ayat ini turun mengenai aktivitas kebiasaan masyarakat kota Madinah yang terbiasa saling menghutangkan buah-buahan untuk

\footnotetext{
${ }^{6}$ Muhammad Fuad Abdul Baqi, Tafshîl âyât al-Quran al-Hakîm, 2012, Tafsir Tematis Ayat-Ayat AlQuran Al-Hakim, Terjemahan KH. Ahmad Sunarto, (Surabaya: Halim Jaya), 156.

${ }^{7}$ Ibid, 158.
} 
masa satu hingga dua tahun.Maka Rasulullah Saw. Bersabda,

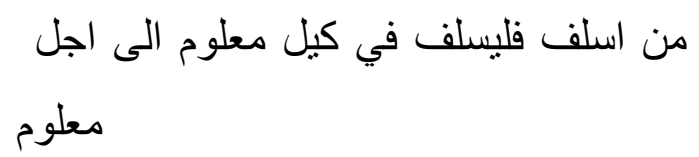

"barang siapa yang berutang maka hendaklah ia berhutang dalam takaran yang diketahui dan dalam tempo yang diketahui". Tak selang berapa lama, turunlah ayat ini. ${ }^{8}$

Al-Baqarah ayat 283

Sementara ini penulis tidak menemukan asbabun nuzul dari ayat ini.

\section{KESIMPULAN}

Pembahasan diatas sudah banyak mengurai tentang tata cara utang piutang yang diajarkan oleh alquran terutama dalam surat al-Baqarah 282 dan ayat 283. Yang mana membahas mengenai pembahasan utang piutang, maka dapat disimpulkan bahwa;

1. Dalam agama islam prilaku utang piutang diperkenankan asal dengan bil baik dan benar sesuai ketentuan agama.

2. Dalam transaksi utang piutang setiap muslim diwajibkan untut mencatat setiap utang yang dilakukan, karena dengan begitu akan mengantisipasi hal-hal buruk yang akan terjadi selama proses akad masih berlangsung.

${ }^{8}$ Al-Imam Abu Fida Ismail Ibnu Katsir, Tafsîr Ibnu Katsîr, terjemahan Bahrun Abu Bakar, 185. 


\section{DAFTAR PUSTAKA}

al-Fauzan, Saleh. 2005. Al-Mulakhkhasul Fiqhi. Jakarta: Gema Insani Pres.

Baqi, Muhammad Fuad Abdul. 2012. Tafshîl âyât al-Quran alHakîm.

Fikri, Ali. 1356 H. Al-Muamalat Al-Maddiyah wa Al-Adabiyah. Mesir: Mushtafa Al-Babiy Al-Halabiy.

Katsir, Al-Imam Abu Fida Ismail Ibnu. Tafsîr Ibnu Katsîr, terjemahan Bahrun Abu Bakar.

Sabiq, Sayyid. 1981. Fiqh As-Sunnah, Juz 3, Dar Al-Fikr cet, 3.

Sunarto, Ahmad. Tafsir Tematis Ayat-Ayat AlQuran Al-Hakim, Surabaya: Halim Jaya.

Syafei, Rachmat. Fiqh Muamalah. Bandung:CV. Pustaka Setia.

Zuhaily, Wahbah. 1985. Fiqih Islam Wa Adilatuhu. Beirut. Damaskus.Darul fikr. cet.2. 